\title{
Two new erigonine spiders from Nepal (Aranei: Linyphiidae)
}

\section{Ава новых вида пауков-эригонин из Непала (Aranei: Linyphiidae)}

\author{
A.V. Tanasevitch \\ A.В. Танасевич
}

A.N. Severtsov Institute of Ecology and Evolution, Russian Academy of Sciences, Leninsky prospekt 33, Moscow 119071, Russia. E-mail: tanasevitch@gmail.com

Институт проблем экологии и эволюции им. А.Н. Северцова РАН, Ленинский проспект 33, Москва 119071, Россия.

KEY WORDS: taxonomy, Arachnida, Erigoninae, Himalayas, mountain fauna.

КЛЮЧЕВЫЕ СЛОВА: таксономия, Arachnida, Erigoninae, Гималаи, горная фауна.

ABSTRACT. Two new linyphiid spiders from the subfamily Erigoninae, Erigone acuta sp.n. $\left(O^{7}\right)$ and Gongylidiellum koshi sp.n. ( $\sigma^{\top} \&$ \&), are described from the Nepal Himalayas. Erigone acuta sp.n. somewhat resembles E. autumnalis Emerton, 1882, while $G$. koshi sp.n. is similar to G. nepalense Wunderlich, 1983. Both new species can easily be distinguished from their congeners mainly by certain details of the genitalic structure.

How to cite this paper: Tanasevitch A.V. 2021. Two new erigonine spiders from Nepal (Aranei: Linyphiidae) // Arthropoda Selecta. Vol.30. No.1. P.125-129. doi: 10.15298/arthsel.30.1.12

РЕЗЮМЕ. Из непальских Гималаев описаны два новых вида линифиид подсемейства Erigoninae: Erigone acuta sp.n. $\left(\mathrm{O}^{\text {т }}\right)$ и Gongylidiellum koshi sp.n. $\left(\sigma^{\top}\right.$ и + ). Erigone acuta sp.n. отчасти напоминает $E$. autumnalis Emerton, 1882, G. koshi sp.n. наиболее близок к G. nepalense Wunderlich, 1983. Оба вида легко отличимы от ближайших деталями строения гениталий.

\section{Introduction}

The spider fauna of the Himalayas presently includes seven species of the genus Erigone Audouin, 1826 , three of them from Nepal. Erigone atra Blackwall, 1833 has been reported from the highlands of Nepal (5030-5100 m a.s.1.), E. prominens Bösenberg et Strand, 1906 from medium elevations (2400-3200 m a.s.1.), while E. nepalensis Wunderlich, 1983 has been described from $3300 \mathrm{~m}$ a.s.l. [Wunderlich, 1983].

The genus Gongylidiellum Simon, 1884 is currently represented in the Himalayas by four species, two of which are known from Nepal: G. kathmanduense Wunderlich, 1983, described from 2100-2700 m a.s.1., and G. nepalense Wunderlich, 1983, from 2500-3400 m a.s.1. [Wunderlich, 1983].

A recent study of material from the Himalayas, kept at the Muséum d'histoire naturelle de Genève, Switzerland (MHNG), has revealed a couple of new species, one each in Erigone and Gongylidiellum. Their descriptions are the subject of the present paper.

\section{Material and methods}

This paper is fully based on material kept at the MHNG. Sample numbers are given in square brackets. Specimens preserved in 70\% ethanol were studied using a MBS-9 stereomicroscope. A Levenhuk C-800 digital camera was used for photos. Leg chaetotaxy is presented in a formula, e.g., 1.1.1.1 or 2.2.1.1, which refers to the number of dorsal spines on tibiae I-IV. The sequence of leg segment measurements is as follows: femur + patella + tibia + metatarsus + tarsus. All measurements are given in $\mathrm{mm}$. Scale lines in the figures correspond to $0.1 \mathrm{~mm}$ unless indicated otherwise. Figure numbers are given above the scale lines, the alternative distance below them.

The terminology of copulatory organs mainly follows that of Merrett [1963] and those of the authors mentioned in the Abbreviations section below.

The following abbreviations are used in the text and figures: a.s.l. — above sea level; DSA — distal suprategular apophysis sensu Hormiga [2000]; E - embolus; ED embolic division; EM - embolic membrane sensu Tanasevitch [2017], not sensu van Helsdingen [1986] and Hormiga [1994]; EP — embolus proper sensu Saaristo [1971]; MeRT - mesal radical tooth of embolic division (= mesal tooth sensu Crosby \& Bishop [1928]); MM — median membrane sensu Helsdingen [1965] (= embolic membrane sensu van Helsdingen [1986] and Hormiga [1994]); Mt — metatarsus; P - paracymbium; PMP - posterior median plate sensu Helsdingen et al. [1977] (= dorsal plate, median plate, central capsule, auct.); PRA - posterior radical apophysis (= posterior tooth sensu Crosby \& Bishop [1928]); R radix; TmI - position of trichobothrium on metatarsus I.

\section{Descriptions}

Order Aranei Clerck, 1758

Family Linyphiidae Blackwall, 1859 Subfamily Erigoninae Emerton, 1882 


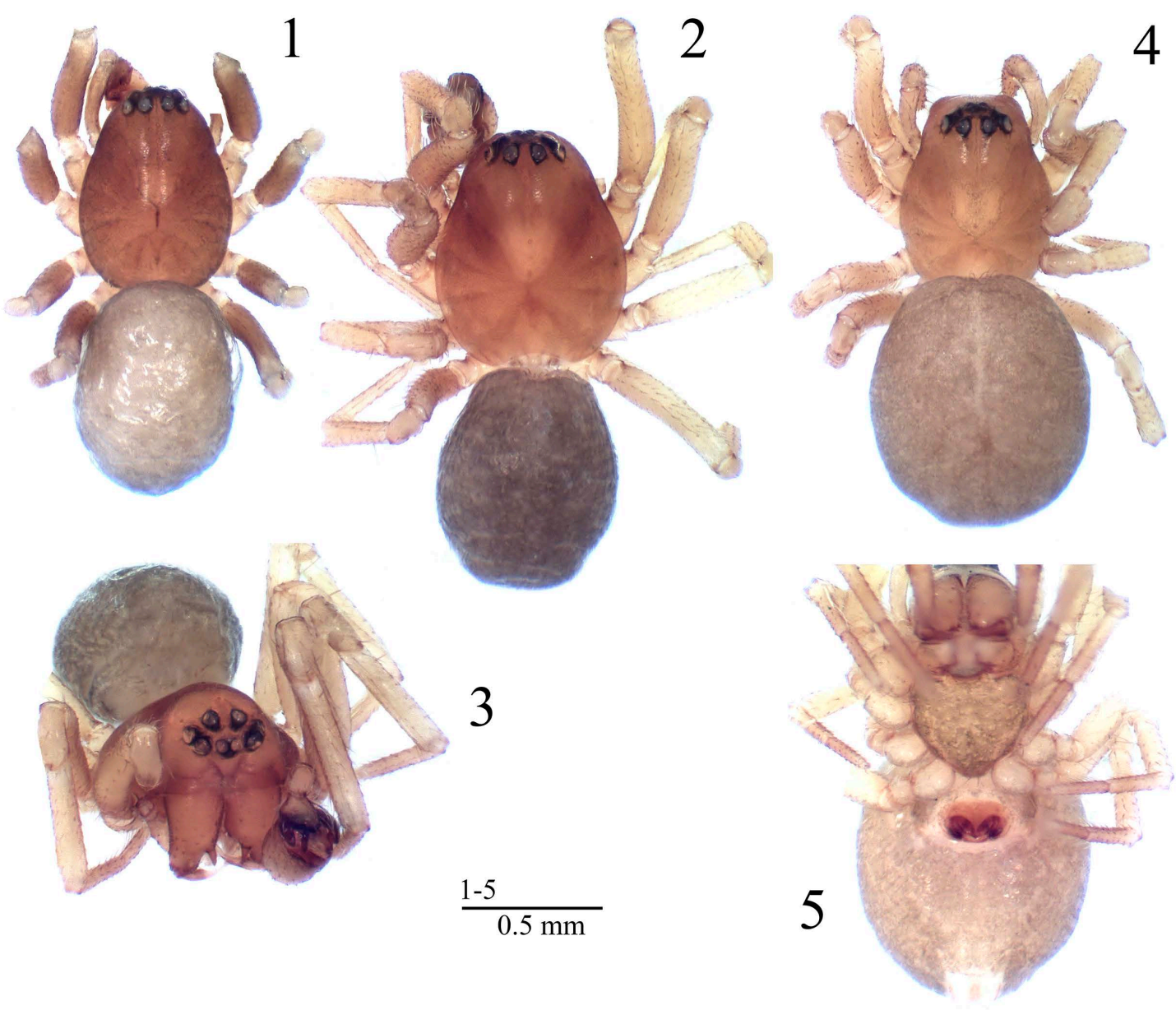

Figs 1-5. Photographs of Erigone acuta sp.n., $0^{7}$ holotype (1), Gongylidiellum koshi sp.n., $\bigcirc^{7}$ holotype (2-3) and $\odot$ paratype (4-5). 15 - body, 1, 2, 4 - dorsal view, 3 - frontal view, 5 - ventral view.

Рис. 1-5. Фотографии Erigone acuta sp.n., О7 голотип (1), Gongylidiellum koshi sp.n., ơ голотип (2-3) и + паратип (4-5). 1-5 внешний вид, 1, 2, 4 - вид сверху, 3 - вид спереди, 5 - вид снизу.

\section{Erigone acuta sp.n.}

Figs 1, 6-10.

HOLOTYPE $\sigma^{\top}$ (MHNG), NEPAL, Kosi (= Koshi) Province, Sankhuwasawa (= Sankhuwasabha) District, east side of Goru Dzure Dara, $3350 \mathrm{~m}$ a.s.l., sifting mosses, ferns and herbs, 9.IV.1984, leg. I. Löbl \& A. Smetana [12].

NAME. The specific epithet is a Latin adjective, meaning "sharpened, pointed", referring to the spike-shaped embolic membrane.

DESCRIPTION. Male holotype. Total length 1.43. Carapace unmodified (Fig. 1), 0.70 long, 0.53 wide, pale brown. Lateral edges of carapace toothless, its cephalic part not elevated. Chelicerae 0.30 long, a mastidion absent. Legs pale brown. Leg I, 1.77 long $(0.48+0.18+0.40+0.38+$ $0.33)$, IV, 1.87 long $(0.53+0.18+0.48+0.38+0.30)$. Chaetotaxy 1.1 .1 .1 , spines $1-1.5$ diameters of corresponding leg segment. Metatarsus IV without trichobothrium. TmI 0.43. Palp (Figs 6-10): Patella small, rounded, a typical distal ventro-apical apophysis absent. Tibia slightly elongated, ending sharp. Paracymbium U-shaped. Distal suprategular apophysis elongated, well-sclerotized, rounded distally. Embolic membrane sclerotized, widened proximally, with a serrate edge, its distal part spike-shaped. Posterior radical apophysis relatively long, slightly curved, not widening dis- tally, serrate apically. Embolus proper very short, knobshaped. Abdomen 0.78 long, 0.55 wide, pale grey.

Female unknown.

TAXONOMIC REMARKS. The new species somewhat resembles E. autumnalis Emerton, 1882, originally known from North and Central America, introduced to the Azores, Europe, the United Arab Emirates, and New Caledonia [Word Spider Catalog, 2020]. Erigone acuta sp.n. can easily be distinguished by the absence of a distal ventro-apical apophysis on the palpal patella, by a missing terminal knob on the posterior radical apophysis, as well as by the untypical chaetotaxy formula, 1.1.1.1 versus 2.2.2.1 in Erigone. This case is not unique, as another non-typical chaetotaxy formula, i.e. 2.2.1.1, is also known to occur in some Oriental congeners, i.e. E. bifurca Locket, 1982, E. apophysalis Tanasevitch, 2017 and E. sumatrana Tanasevitch, 2017 (see Tanasevitch [2017]).

DISTRIBUTION. Known from the type locality only.

\section{Gongylidiellum koshi sp.n.}

Figs 2-5, 11-17.

HOLOTYPE $0^{7}$ (MHNG), NEPAL, Kosi (= Koshi) Province, Sankhuwasawa (= Sankhuwasabha) District, Induwa Kola Valley, 

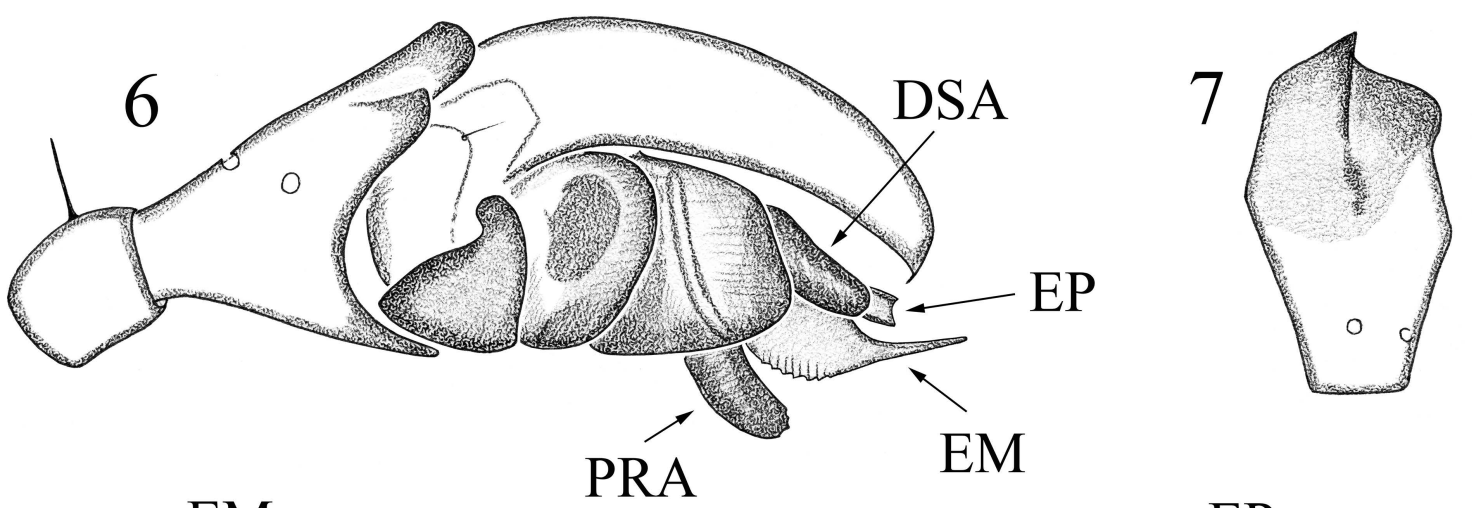

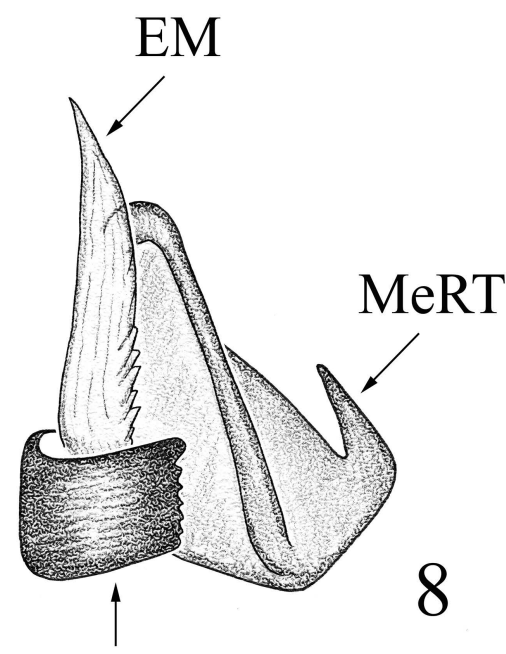

PRA
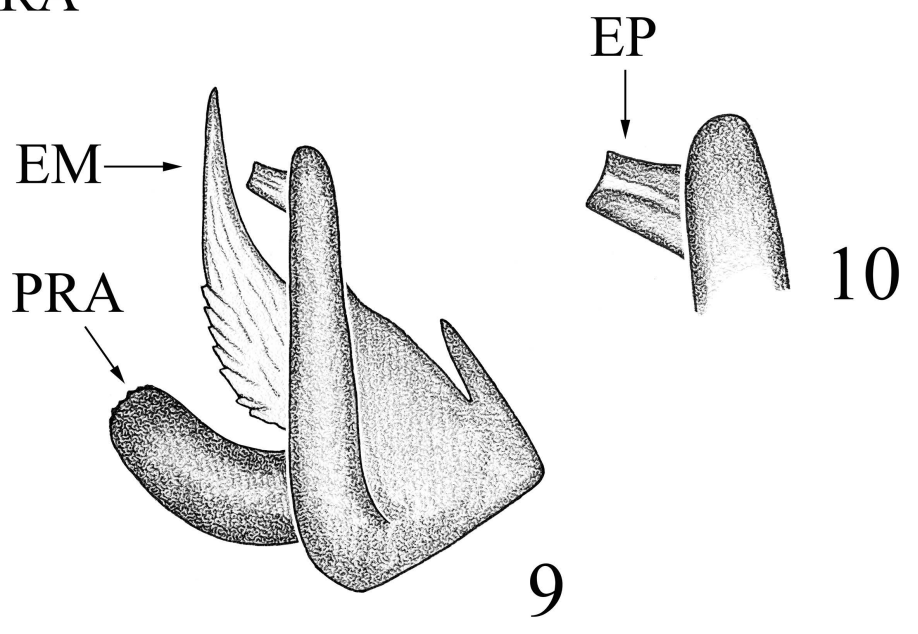

6-7

8-9

Figs 6-10. Details of male palpal structure of Erigone acuta sp.n., $\sigma^{7}$ holotype. 6 - right palp, retrolateral view; 7 - palpal tibia, dorsal view; 8-9-embolic division, different aspects; 10 - embolus proper. Fig. 10, not to scale.

Рис. 6-10. Детали строения пальпы самца Erigone acuta sp.n., о7 голотип. 6 - правая пальпа, ретролатерально; 7 - голень пальпы, вид сверху; 8-9 - эмболюсный отдел, различные аспекты; $10-$ собственно эмболюс. Рис. 10 не в масштабе.

2800 m a.s.1., sifting dead leaves of Rhododendrons and Bamboo at foot of rocks, 15.IV.1984, leg. I. Löbl \& A. Smetana [22].

PARATYPE. 1 ( $\mathrm{MHNG}$ ), collected together with the holotype.

NAME. The specific epithet is a name in apposition referring to the territory of origin, Koshi Province, Nepal.

DESCRIPTION. Male holotype. Total length 1.63. Carapace unmodified (Fig. 2), 0.83 long, 0.68 wide, pale brown. Chelicerae 0.33 long, mastidion as a sharp tooth in distal part of chelicera (Fig. 3). Legs pale brown. Leg I, 2.26 long $(0.63+0.20+0.55+0.50+0.38), \mathrm{IV}, 2.29$ long $(0.55+$ $0.20+0.53+0.48+0.53)$. Chaetotaxy 2.2.1.1, spines $1-1.5$ diameters of corresponding leg segment or spines lost. Metatarsus IV without trichobothrium. TmI 0.34. Palp (Figs 1115): Tibia short and wide, with a dark, prolateral, slightly curved process. Paracymbium L-shaped. Median membrane small, swollen. Distal suprategular apophysis well-sclerotized, almost black. Radix large, flat, darkened distally. Embolus relatively short and wide. Abdomen 1.00 long, 0.65 wide, pale grey.

Female. Total length 1.60. Carapace unmodified (Fig. 4), 0.70 long, 0.55 wide, yellow to pale brown. Chelicerae
0.30 long, a mastidion absent. Legs yellow to pale brown. Leg I, 1.85 long $(0.48+0.23+0.43+0.38+0.33)$, IV, 1.76 long $(0.50+0.30+0.43+0.35+0.28)$. Chaetotaxy as in male. TmI 0.32. Abdomen 0.95 long, 0.80 wide, pale grey. Epigyne as in Figs 5, 16-17. Epigynal cavity a subrectangular box. Anterior wall with a small, pointed projection, somewhat overhanging the cavity. Receptacles narrow, oblong.

TAXONOMIC REMARKS. The new species seems to be especially similar to G. nepalense Wunderlich, 1983, widespread in the Nepal Himalayas [Wunderlich, 1983], but the male is distinctly distinguished by the shape of the radix and embolus (Fig. 15 cf. Wunderlich, 1983: figs 55-56). The female differs by a twice as wide anterior wall of the epigyne.

DISTRIBUTION. Known from the type locality only.

Acknowledgements. I am deeply grateful to Peter Schwendinger (MHNG) for offering the opportunity to work on the arachnological collections under his care. Thanks also go to Sergei Golovatch for editing this paper. This study was supported in part by the Presidium of the Russian Academy 


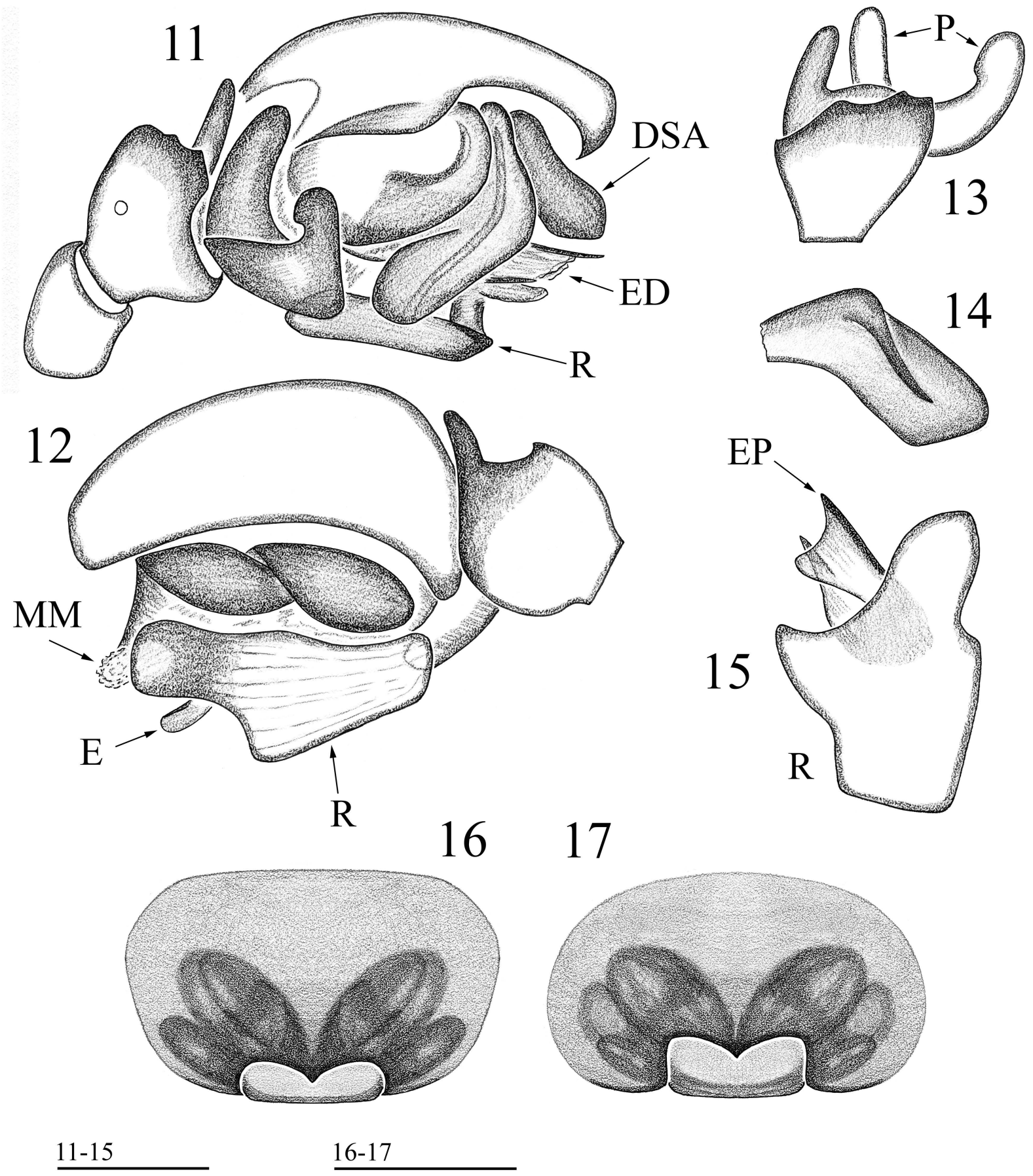

Figs 11-17. Details of male palpal structure and female epigyne of Gongylidiellum koshi sp.n., $0^{7}$ holotype (11-15), and $\odot$ paratype (16-17). 11-12 - right palp, retrolateral and prolateral views, respectively; 13 - palpal tibia and paracymbium, dorsal view; 14 - distal suprategular apophysis; 15 - embolic division; 16-17 - epigyne, ventral view, different aspects.

Рис. 11-17. Детали строения пальпы самца и эпигины самки Gongylidiellum koshi sp.n., о7 голотип (11-15) и + паратип (1617). 11-12 - правая пальпа, ретролатерально и пролатерально, соответственно; 13 - голень пальпы и парацимбиум, вид сверху; 14 - дистальная супратегулярная апофиза; 15 - эмболюсный отдел; 16-17 - эпигина, вид снизу, различные аспекты. 
of Sciences, Program No. 41 "Biodiversity of natural systems and biological resources of Russia".

\section{References}

Crosby C.R., Bishop S.C. 1928. Revision of the spider genera Erigone, Eperigone and Catabrithorax (Erigoneae) // New York State Museum Bulletin. No.278. P.1-73.

Helsdingen P.J. van. 1965. Sexual behaviour of Lepthyphantes leprosus (Ohlert) (Araneida, Linyphiidae), with notes on the function of the genital organs // Zoologische Mededelingen. Bd.41. P.15-42.

Helsdingen P.J. van. 1986. World distribution of Linyphiidae // Eberhard W.E., Lubin Y.D., Robinson B.C. (eds.). Proceedings of the Ninth International Congress of Arachnology, Panama 1983. Smithsonian Institution Press, Washington D.C. P.121-126.

Helsdingen P.J. van, Thaler K., Deltshev C. 1977. The tenuis group of Lepthyphantes Menge (Araneae, Linyphiidae) // Tijdschrift voor Entomologie. Vol.120. P.1-54.

Hormiga G. 1994. Cladistics and the comparative morphology of linyphiid spiders and their relatives (Araneae, Araneoidea, Linyphiidae) // Zoological Journal of the Linnean Society. Vol.111. P.1-71.
Hormiga G. 2000. Higher level phylogenetics of erigonine spiders (Araneae, Linyphiidae, Erigoninae) // Smithsonian Contributions to Zoology. Vol.609. P.1-160.

Merrett P. 1963. The palpus of male spiders of the family Linyphiidae // Proceedings of the Zoological Society of London. Vol.140. P.347-467.

Saaristo M.I. 1971. Revision of the genus Maro O. P.-Cambridge (Araneae, Linyphiidae) // Annales Zoologici Fennici. Vol.8. P.463-482.

Saaristo M.I., Tanasevitch A.V. 1996. Redelimitation of the subfamily Micronetinae Hull, 1920 and the genus Lepthyphantes Menge, 1866 with descriptions of some new genera (Aranei, Linyphiidae) // Berichte des Naturwissenschaftlich-Medizinischen Vereins in Innsbruck. Bd.83. P.163-186.

Tanasevitch A.V. 2017. New species and new records of linyphiid spiders from the Indo-Malayan Region (Araneae: Linyphiidae) // Zootaxa. Vol.4227. No.3. P.325-346.

World Spider Catalog 2020. World Spider Catalog, version 21.5. Natural History Museum Bern. Online at http://wsc.nmbe.ch (accessed in October, 2020).

Wunderlich J. 1983. Linyphiidae aus Nepal, IV. Bisher unbekannte und für Nepal neue Arten (Arachnida: Araneae) // Senckenbergiana Biologica. Bd.63. S.219-248.

Responsible editor K.G. Mikhailov 